\title{
Diazotrophic growth of the unicellular cyanobacterium Gloeothece sp. PCC 6909 in continuous culture
}

\author{
José-Julio Ortega-Calvo $\dagger$ and Lucas J. Stal* \\ Laboratory for Microbiology, University of Amsterdam, Nieuwe Achtergracht 127, 1018 WS Amsterdam, \\ The Netherlands
}

(Received 29 November 1990; revised 4 March 1991; accepted 30 April 1991)

\begin{abstract}
The unicellular cyanobacterium Gloeothece sp. PCC 6909 was grown diazotrophically in continuous culture. Various light-dark regimes and dilution rates were applied. Nitrogenase activity (acetylene reduction), oxygenproduction and -consumption, and glycogen were measured over $24 \mathrm{~h}$ periods covering one complete light-dark cycle. Gloeothece fixed nitrogen predominantly in the light, concomitant with photosynthetic oxygen evolution. This result was found irrespective of the imposed light-dark regime or dilution rate. It is concluded that temporal separation of photosynthesis and nitrogen fixation is not obligatory in Gloeothece.
\end{abstract}

\section{Introduction}

Gloeothece is a unicellular cyanobacterium capable of fixing nitrogen aerobically (Wyatt \& Silvey, 1969). Nitrogenase is known to be extremely oxygen-sensitive (Robson \& Postgate, 1980), and since cyanobacteria evolve oxygen during photosynthesis they need specific adaptations to protect the enzyme from inactivation. Two groups of nitrogen-fixing cyanobacteria can be recognized based on the type of adaptation. Many filamentous cyanobacteria realize a spatial separation of nitrogen fixation, which is carried out in specialized cells known as heterocysts, and oxygenic photosynthesis, which is located in the vegetative cells (Wolk, 1982). The remaining filamentous and unicellular cyanobacteria perform oxygenic photosynthesis and nitrogen fixation in undifferentiated cells. A general mechanism of the latter group is hypothesized to be a temporal separation of oxygenic photosynthesis and nitrogen fixation (Gallon \& Chaplin, 1988; Grobbelaar et al., 1987; Kallas et al., 1983; Leon et al., 1986; Mitsui et al., 1986; Stal \& Krumbein, 1987).

All non-heterocystous nitrogen-fixing cyanobacteria described thus far are able to grow diazotrophically under continuous light. However, this does not necessarily mean that such organisms carry out oxygenic

$\dagger$ Present address: Instituto de Recursos Naturales y Agrobiologia de Sevilla, CSIC, PO Box 1052, 41080 Sevilla, Spain.

\footnotetext{
Abbreviations: Chl $a$, chlorophyll $a ; D$, dilution rate; FID, flame ionization detector; PFD, photon flux density.
}

photosynthesis and nitrogen fixation simultaneously in the same cell. A culture may consist of cells that are in different physiological states, some of them fixing nitrogen while oxygenic photosynthesis is switched off. If non-heterocystous, nitrogen-fixing cyanobacteria are grown under an imposed cycle of alternating light and dark periods, a temporal separation of oxygenic photosynthesis and nitrogen fixation is achieved with the latter process occurring predominantly during the dark phase. Several authors have reported that, if such cultures are switched to continuous light, the cyclic behaviour of nitrogenase is conserved (Grobbelaar et al., 1986; Mitsui et al., 1986; Stal \& Krumbein, 1987). Mitsui et al. (1987) concluded from work with the synchronously growing marine unicellular Synechococcus sp. strain Miami BG 043511 that nitrogen fixation and oxygenic photosynthesis were confined to different stages of the celldivision cycle. On the other hand, Huang et al. (1990) presented evidence that the endogenous rhythm of nitrogenase in Synechococcus sp. RF-1, isolated from a rice field, might be controlled by a circadian clock, and thus would be independent of the cell-division cycle.

Attempts to grow Gloeothece sp. synchronously have failed (Gallon et al., 1988). When this organism was grown under an alternating 12-12 h light-dark cycle, a doubling time of $69 \mathrm{~h}$ was reported, but nitrogenase activity appeared during the dark phases with a periodicity of $24 \mathrm{~h}$. These observations make it unlikely that nitrogen fixation in Gloeothece is confined to a certain stage of the cell-division cycle. Reguiation through a circadian clock seems very improbable in 
Gloeothece because a culture grown under a 12-12 h light-dark regime and switched to continuous light did not maintain the cyclic pattern of nitrogenase activity for more than one cycle (Gallon et al., 1988). Therefore, the mechanism of oxygen protection of nitrogenase in Gloeothece might be different. Gallon et al. (1988) suggested that 'specific metabolic changes are responsible for the pattern of nitrogen fixation observed during alternating light and darkness,' but the nature and the regulatory aspects of these specific metabolic changes are still obscure.

Culture conditions deserve great attention since they may exert an important influence on the physiological state and behaviour of the cell. In view of the high demand of nitrogenase for energy and low-redoxpotential electrons, and its sensitivity towards oxygen, both light intensity and oxygen concentration are extremely important culture parameters. Here we report results on diazotrophic growth, nitrogen fixation and photosynthesis of a Gloeothece sp. grown under welldefined conditions in continuous culture. The results obtained are very different from those derived from batch cultures. We show that a temporal separation of nitrogen fixation and oxygenic photosynthesis is not an obligatory prerequisite for diazotrophic growth of Gloeothece sp. PCC 6909.

\section{Methods}

Organism and growth conditions. Gloeothece sp. strain PCC 6909 was obtained from the Pasteur Culture Collection (Paris, France). The cyanobacterium was grown in medium BG $11_{0}$ lacking a source of combined nitrogen (Rippka et al., 1979). The culture was maintained in $300 \mathrm{ml}$ Erlenmeyer flasks containing $150 \mathrm{ml}$ of liquid medium and incubated on an orbital shaking platform at $20^{\circ} \mathrm{C}$ with a light intensity of $16 \mu \mathrm{E} \mathrm{m}^{-2} \mathrm{~s}^{-1}$, provided by Philips TLD $18 \mathrm{~W} / 33$ fluorescent tubes. Stock cultures were transferred to fresh medium every 6 weeks. Continuous cultures were constructed as described in Van Liere \& Mur (1978). The source of light consisted of one or two cold white circular fluorescent tubes (Philips TLE 32W/33) that were placed symmetrically around the culture vessel, which was a modified 21 Kluyver flask. Three different light-dark cycles were used: $16-8,12-12$ and $8-16 \mathrm{~h}$ light-dark. The cultures were aerated with sterile air at a rate of $\pm 11 \mathrm{~min}^{-1}$. Air was introduced from the bottom of the modified Kluyver flask which was made of sintered glass. This gave finely dispersed air bubbles and guaranteed very good gas exchange. This aeration was sufficient to keep the cells in suspension and guaranteed a concentration of dissolved oxygen which equalled air saturation at all times. Steady states in continuous cultures can only be obtained if all parameters are kept constant at all times. This is obviously not the case when alternating light-dark cycles are applied. However, the cultures will reach a time-dependent equilibrium, i.e. the properties of the culture are constant only if measured at the same point of time in the light-dark cycle (De Wit \& Van Gemerden, 1990). In our hands the cultures reached a time-dependent equilibrium after three (at low dilution rate, $D$ ) or five (at high dilution rate) volume changes. The cultures with $D=0.005$ and $0.007 \mathrm{~h}^{-1}$ were sampled after three volume changes and the one with $D=0.015 \mathrm{~h}^{-1}$ after five volume changes. The culture with $D=0.02 \mathrm{~h}^{-1}$ was sampled after five volume changes, but this culture did not reach equilibrium because the dilution rate exceeded the critical value, and the culture was washed out slowly.

Nitrogenase activity. Every hour, $2 \mathrm{ml}$ samples were withdrawn aseptically from the continuous cultures and pipetted into a $12 \mathrm{ml}$ tube which was then sealed with a rubber stopper. Acetylene $(2 \mathrm{ml})$ was injected and the sample was incubated for $1 \mathrm{~h}$ in the dark or light, according to the culture light-dark cycle. For dark incubation, the tubes were wrapped in aluminium foil. Light incubations were done with incident irradiance of $43 \mu \mathrm{E} \mathrm{m}^{-2} \mathrm{~s}^{-1}$ (Philips TLE 32W/33). Tubes were incubated horizontally to allow maximum surface area for gas exchange, and the temperature was maintained at $20^{\circ} \mathrm{C}$. The measurements were done in triplicate. Acetylene and ethylene were determined by gas chromatography after $1 \mathrm{~h}$ of incubation (Varian 2400 , equipped with a flame ionization detector (FID), connected to an LDC/Milton Roy CI-10 integrator). The 3-m-long glass column was packed with Porapak type $R$, mesh $80-100$. The carrier gas was nitrogen at a flow rate of $30 \mathrm{ml} \mathrm{min}{ }^{-1}$. The flow of hydrogen and air for the FID were 20 and $200 \mathrm{ml} \mathrm{min}^{-1}$, respectively. The oven, injector and detector temperatures were 35,70 and $90^{\circ} \mathrm{C}$, respectively. The volume of the gas sample injected was $200 \mu$ l. Acetylene was used as an internal standard (Stal, 1988).

Photosynthesis and respiration. Photosynthesis and respiration were determined by measuring the rate of oxygen production or consumption. Every hour, $2 \mathrm{ml}$ samples were withdrawn from the continuous cultures and placed into a custom-made oxygen cell provided with a water jacket maintained at $20^{\circ} \mathrm{C}$. An oxygen electrode of the Clark type (model 5331, Yellow Springs Instruments) was used with a custommade voltage source (adjusted to $0.75 \mathrm{~V}$ ) and connected to a Keithley model 485 autoranging picoammeter. A small magnetic bar stirred the sample. For the measurements of photosynthesis, an incident irradiance of $43 \mu \mathrm{E} \mathrm{m}^{-2} \mathrm{~s}^{-1}$ (Philips TLE 22W/33) was used. Respiration was measured in complete darkness. Oxygen production or consumption was recorded automatically by the picoammeter. To minimize alteration of the physiological state of cells, incubations did not exceed $15 \mathrm{~min}$.

Determination of cell components. Optical density of the culture was determined spectrophotometrically at $720 \mathrm{~nm}\left(\mathrm{OD}_{720}\right)$. This measurement was done on samples withdrawn from the continuous culture at the end of the light period.

For chlorophyll $a(\mathrm{Chl} a)$ determination, $5 \mathrm{ml}$ of culture was centrifuged $\left(10 \mathrm{~min}, 4000 \mathrm{~g}, 4^{\circ} \mathrm{C}\right)$ and the pellet was extracted with methanol for $1 \mathrm{~h}$ at room temperature in the dark. The extracts were centrifuged again $\left(10 \mathrm{~min}, 4000 \mathrm{~g}, 4^{\circ} \mathrm{C}\right)$ and the absorption of the methanolic supernatant was measured at $665 \mathrm{~nm}$. The $\mathrm{Chl} a$ content was calculated using the specific absorption coefficient of $74.5 \mathrm{ml} \mathrm{mg}^{-1} \mathrm{~cm}^{-1}$ (MacKinney, 1941). Measurements were always done in triplicate.

Protein was determined by the Lowry method. The pellets extracted for the assay of $\mathrm{Chl} a$ were used for protein determination. The pellets were hydrolysed at $100^{\circ} \mathrm{C}$ for $1 \mathrm{~h}$ in $1 \mathrm{ml} 0.5 \mathrm{M}-\mathrm{NaOH}$. All determinations were performed in triplicate. Samples for $\mathrm{Chl} a$ extraction and protein determination were taken at $4 \mathrm{~h}$ intervals during the light-dark cycle.

Total cell nitrogen was determined after Kjeldahl digestion (Herbert et al., 1971). All determinations were performed in triplicate. Samples $(50 \mathrm{ml})$ for total nitrogen determination were taken at the end of the light period.

Glycogen was determined in $2 \mathrm{ml}$ samples of the cultures. Samples were taken from the continuous culture at $2 \mathrm{~h}$ intervals. The samples were centrifuged for $5 \mathrm{~min}$ in an Eppendorf centrifuge and the pellets were hydrolysed for $1.5 \mathrm{~h}$ at $100{ }^{\circ} \mathrm{C}$ in $200 \mu \mathrm{l} \mathrm{30 \%}$ (w/v) $\mathrm{KOH}$. After cooling, $600 \mu \mathrm{l}$ ice-cold absolute ethanol was added and the polymeric 
carbohydrates were allowed to precipitate for either $2 \mathrm{~h}$ on ice or overnight at $-20^{\circ} \mathrm{C}$. The precipitated carbohydrate was washed in icecold ethanol and then hydrolysed for $30 \mathrm{~min}$ at $100^{\circ} \mathrm{C}$ in $1 \mathrm{ml} 2 \mathrm{M}-\mathrm{HCl}$. After cooling, $1 \mathrm{ml} 2 \mathrm{M}-\mathrm{NaOH}$ and $3 \mathrm{ml} 200 \mathrm{~mm}$-potassium phosphate buffer ( $\mathrm{pH} \mathrm{7.0)}$ were added. The glucose content of this solution was measured using the GOD-Perid method (Boehringer).

Light measurement. Light was measured with a LI-Cor model LI-185B Quantum/Radiometer/Photometer equipped with an LI-190SB Quantum sensor. Mean culture photon flux density (PFD) was determined according to Van Liere et al. (1978). Mean PFD $\left(\mu \mathrm{E} \mathrm{m}^{-2} \mathrm{~s}^{-1}\right)$ makes allowance for the length of the light period and for culture density, and is an estimate of the average light irradiance in the culture over $24 \mathrm{~h}$.

\section{Results}

The unicellular cyanobacterium Gloeothece sp. PCC 6909 was grown under nitrogen-fixing conditions in continuous cultures. Various dilution rates, light intensities and light-dark cycles were employed. However, attempts to grow a culture under an $8-16 \mathrm{~h}$ light-dark regime failed, regardless of the dilution rate and both at low $\left( \pm 40 \mu \mathrm{E} \mathrm{m}^{-2} \mathrm{~s}^{-1}\right)$ or high $\left( \pm 90 \mu \mathrm{E} \mathrm{m}^{-2} \mathrm{~s}^{-1}\right)$ incident irradiance. Even when the medium pump was switched off, no growth was observed. When applying a 12-12 h light-dark cycle, a stable culture was achieved only at low incident-light intensity $\left(39 \mu \mathrm{E} \mathrm{m}^{-2} \mathrm{~s}^{-1}\right)$ and at a low dilution rate of $0.007 \mathrm{~h}^{-1}$. Higher dilution rates or more light resulted in wash out of the culture. It appeared easier to obtain stable cultures at $16-8 \mathrm{~h}$ alternating light-dark cycles. Equilibrium was obtained at $D=$ 0.005 and $0.015 \mathrm{~h}^{-1}$. At $D=0.020 \mathrm{~h}^{-1}$ the culture was washed out slowly.

Table 3 shows a number of parameters measured in the different cultures. The protein content of the cultures was taken as a measure of biomass. The Chl $a$ content appeared to depend greatly on culture conditions (i.e. light intensity). The culture at $D=0.005 \mathrm{~h}^{-1}$ contained $40 \mu \mathrm{g} \mathrm{Chl} a$ (mg protein) $)^{-1}$ (corresponding to a protein/Chl $a$ ratio of 25). At $D=0.015 \mathrm{~h}^{-1}$ the biomass of the culture decreased to $164 \mu \mathrm{g}$ protein $\mathrm{ml}^{-1}$ but the $\mathrm{Chl} a$ content decreased even more. The protein/Chl $a$ ratio increased to 38 . A dilution rate of $0.020 \mathrm{~h}^{-1}$ probably just exceeded the critical dilution rate $\left(D_{\mathrm{c}}\right)$ and the culture was washed out slowly. This culture was characterized by a very low specific Chl $a$ content and a very high mean PFD of $131.7 \mu \mathrm{E} \mathrm{m}^{-2} \mathrm{~s}^{-1}$. The protein/Chl $a$ ratio was $63: 1$. Also in the $12-12 \mathrm{~h}$ light-dark culture, a very high protein/Chl $a$ ratio of $53: 1$ was observed. The biomass of this culture was low - only $37 \mu \mathrm{g}$ protein $\mathrm{ml}^{-1}$. The concentrations of protein and $\mathrm{Chl} a$ in the culture did not change during a light-dark cycle. The nitrogen content of the cells was equal in all cultures and amounted to $0.23 \mathrm{mg}$ nitrogen (mg protein) ${ }^{-1}$. Since all components in the medium were in excess we would consider these
Table 1. Glycogen content of Gloeothece sp. PCC 6909

Values represent the amounts of glycogen measured at the end of the dark or light periods and are the average of triplicate measurements $\pm \mathrm{SE}$.

\begin{tabular}{lcccc}
\hline \hline \multicolumn{2}{c}{ Culture conditions } & & \multicolumn{2}{c}{$\begin{array}{c}\text { Glycogen } \\
\left.\text { [mg glucose }(\mathrm{mg} \text { protein })^{-1}\right]\end{array}$} \\
\cline { 4 - 5 }$D\left(\mathrm{~h}^{-1}\right)$ & $\begin{array}{c}\text { Light-dark } \\
\text { cycle (h) }\end{array}$ & & Dark & Light \\
\hline 0.005 & $16-8$ & & $0.50 \pm 0.02$ & $0.58 \pm 0.02$ \\
0.015 & $16-8$ & & $0.75 \pm 0.01$ & $0.84 \pm 0.01$ \\
0.020 & $16-8$ & & $1.23 \pm 0.04$ & $1.22 \pm 0.02$ \\
0.007 & $12-12$ & & $0.58 \pm 0.01$ & $1.25 \pm 0.02$ \\
\hline \hline
\end{tabular}

Table 2. Total acetylene reduction during a $24 \mathrm{~h}$ cycle and calculated rate of nitrogen fixation

\begin{tabular}{|c|c|c|c|}
\hline \multicolumn{2}{|c|}{ Culture conditions } & \multirow{2}{*}{$\begin{array}{c}\text { Acetylene reduction } \\
\text { [nmol C }{ }_{2} \mathrm{H}_{4}(\mathrm{mg} \text { protein })^{-1} \\
\left.(24 \mathrm{~h})^{-1}\right]\end{array}$} & \multirow{2}{*}{$\begin{array}{l}\text { Nitrogen fixation } \\
\text { [g nitrogen fixed } \\
(\mathrm{g} \text { nitrogen })^{-1} \mathrm{~h}^{-1} \text { ] }\end{array}$} \\
\hline$D\left(\mathrm{~h}^{-1}\right)$ & $\begin{array}{l}\text { Light-dark } \\
\text { cycle (h) }\end{array}$ & & \\
\hline 0.005 & $16-8$ & 1320 & 0.002 \\
\hline 0.015 & $16-8$ & 6130 & 0.008 \\
\hline 0.020 & $16-8$ & 2305 & 0.003 \\
\hline
\end{tabular}

cultures to be light-limited, but it must be remembered that light may act as an inhibiting substrate since photosynthetically evolved oxygen can result in an inhibition of nitrogenase. Consequently, at high PFD, nitrogenase cannot fulfil the nitrogen requirements for growth of the organism. It is well known that nitrogen limitation in cyanobacteria will give rise to elevated amounts of glycogen and, as can be seen in Table 1, this was the case here. The culture grown at the low dilution rate of $D=0.005 \mathrm{~h}^{-1}$ contained $0.58 \mathrm{mg}$ glycogen $(\mathrm{mg}$ protein $)^{-1}$ at the end of the light period. The presumably nitrogen-deficient cultures $\left(D=0.020\right.$ and $\left.0.007 \mathrm{~h}^{-1}\right)$ contained 1.22 and $1.25 \mathrm{mg}$ glycogen $\left(\mathrm{mg}\right.$ protein) ${ }^{-1}$, respectively. The glycogen content of the culture grown at $D=0.015 \mathrm{~h}^{-1}$ was intermediate and amounted to $0.84 \mathrm{mg}(\mathrm{mg} \text { protein })^{-1}$.

Irrespective of the culture investigated, nitrogenase activity was found exclusively (12-12 h, light-dark) or predominantly ( $16-8 \mathrm{~h}$, light-dark) in the light period (Fig. 1). In the cultures grown under a 16-8 h light-dark cycle, nitrogenase activity was present for most of the time, but an increase was noticed at the end of the dark phase. This pattern was similar in any of the 16-8 h light-dark cycles, irrespective of dilution rate or intensity of irradiation (see also Fig. 2a). Differences were only seen in the magnitude of acetylene reduction (Table 2). 

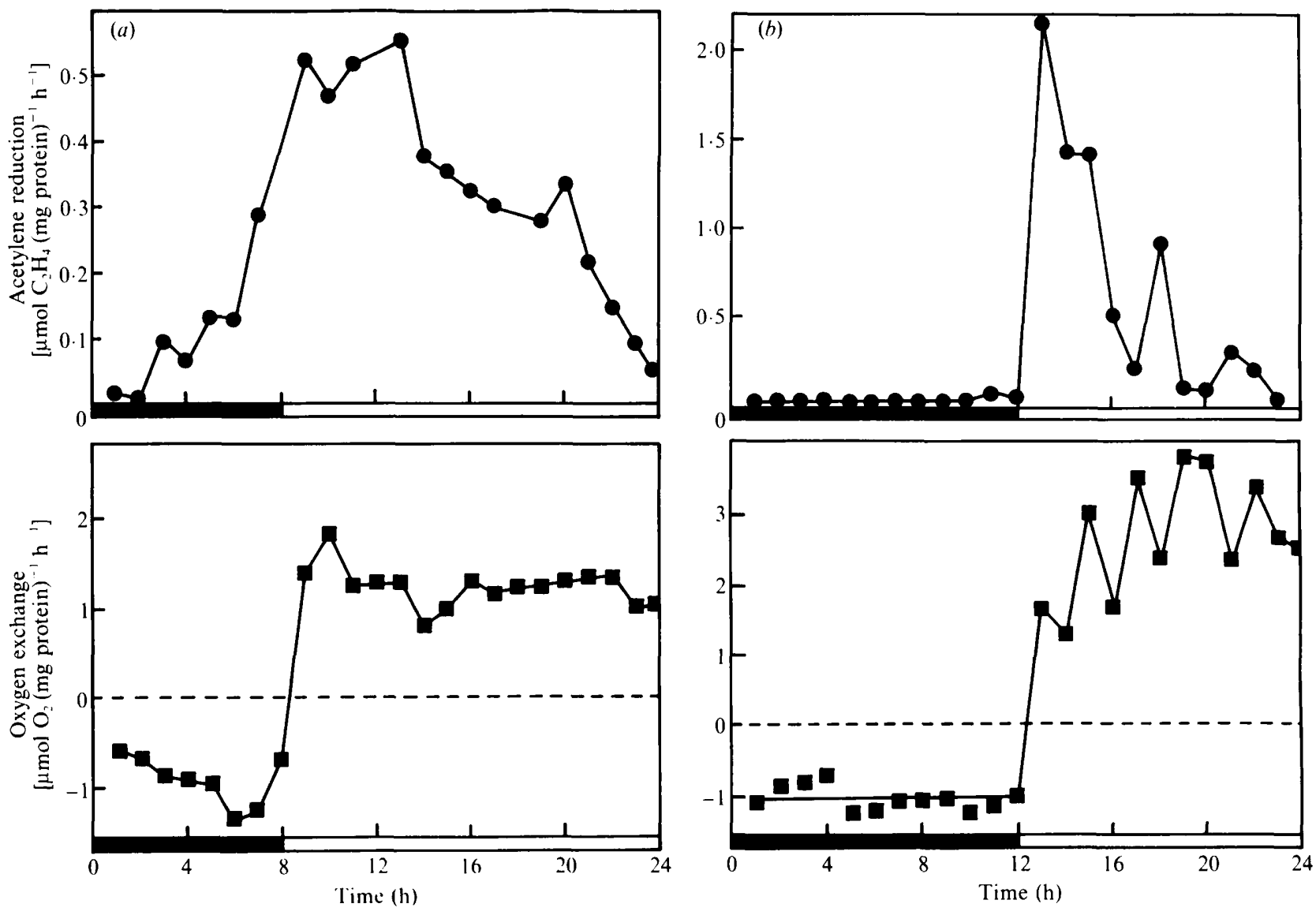

Fig. 1. Pattern of acetylene reduction ( $\bullet$ ) and oxygen exchange ( $\square$ ) in Gloeothece sp. PCC 6909 grown under alternating light-dark cycles in well-aerated continuous cultures. The organism was grown under $(a)$ a $16-8 \mathrm{~h}$ light-dark cycle at $D=0.015 \mathrm{~h}^{-1}$ or $(b)$ a $12-12 \mathrm{~h}$ light-dark cycle at $D=0.007 \mathrm{~h}^{-1}$.

Table 3. Protein, chlorophyll a and nitrogen content of continuous cultures of Gloeothece sp. PCC 6909

\begin{tabular}{|c|c|c|c|c|c|c|c|c|}
\hline \multicolumn{4}{|c|}{ Culture conditions } & \multirow[b]{2}{*}{$\begin{array}{l}\text { Protein } \\
\left(\mu \mathrm{g} \mathrm{ml}^{-1}\right)\end{array}$} & \multirow[b]{2}{*}{$\begin{array}{c}\text { Chl } a \\
\left(\mu \mathrm{g} \mathrm{ml}^{-1}\right)\end{array}$} & \multirow[b]{2}{*}{$\begin{array}{c}\text { Protein/Chl } a \text { ratio } \\
(w / w)\end{array}$} & \multirow[b]{2}{*}{$\begin{array}{l}\text { Nitrogen } \\
\left(\mu \mathrm{g} \mathrm{ml}^{-1}\right)\end{array}$} & \multirow[b]{2}{*}{$\begin{array}{l}\text { Nitrogen/protein ratio } \\
(w / w)\end{array}$} \\
\hline$D\left(\mathrm{~h}^{-1}\right)$ & $\begin{array}{l}\text { Light-dark } \\
\text { cycle }(\mathrm{h})\end{array}$ & Irrad.* & PFD $\dagger$ & & & & & \\
\hline 0.005 & $16-8$ & $79 \cdot 8$ & $25 \cdot 5$ & 216 & $8 \cdot 6$ & 25 & $50 \cdot 4$ & 0.23 \\
\hline 0.015 & $16-8$ & $92 \cdot 7$ & $38 \cdot 2$ & 164 & $4 \cdot 3$ & 38 & $37 \cdot 8$ & $0 \cdot 23$ \\
\hline 0.020 & $16-8$ & $79 \cdot 8$ & $131 \cdot 7$ & 19 & $0 \cdot 3$ & 63 & $4 \cdot 2$ & 0.22 \\
\hline 0.007 & $12-12$ & 38.9 & 49.8 & 37 & 0.7 & 53 & $8 \cdot 4$ & 0.23 \\
\hline
\end{tabular}

* Incident irradiance $\left(\mu \mathrm{E} \mathrm{m}^{-2} \mathrm{~s}^{-1}\right)$.

$\dagger$ PFD, mean photon flux density $\left(\mu \mathrm{E} \mathrm{m}^{-2} \mathrm{~s}^{-1}\right)$.

The total acetylene reduced during a $24 \mathrm{~h}$ cycle may be converted to nitrogen fixed, assuming a ratio of $\mathrm{C}_{2} \mathrm{H}_{2}$ reduced to nitrogen fixed of $4: 1$ (Jensen \& Cox, 1983) and a nitrogen content of the cells of $0.23 \mathrm{~g}$ nitrogen $(\mathrm{g}$ protein $)^{-1}$ (Table 3 ). From these numbers we calculated the specific rate of nitrogen fixation, i.e. the increase of cell nitrogen with time as a function of cell nitrogen, which theoretically should be the same as the specific growth rate. The calculated values were $2-2 \cdot 5$-fold lower than the dilution rate (Table 2).

The increase of nitrogenase activity at the end of the dark period coincided with an increase in respiratory activity (Fig. 1b). Respiration increased from 0.63 to $1.41 \mu \mathrm{mol} \mathrm{O}_{2} \mathrm{~h}^{-1}$ (mg protein $)^{-1}$. Net photosynthetic 

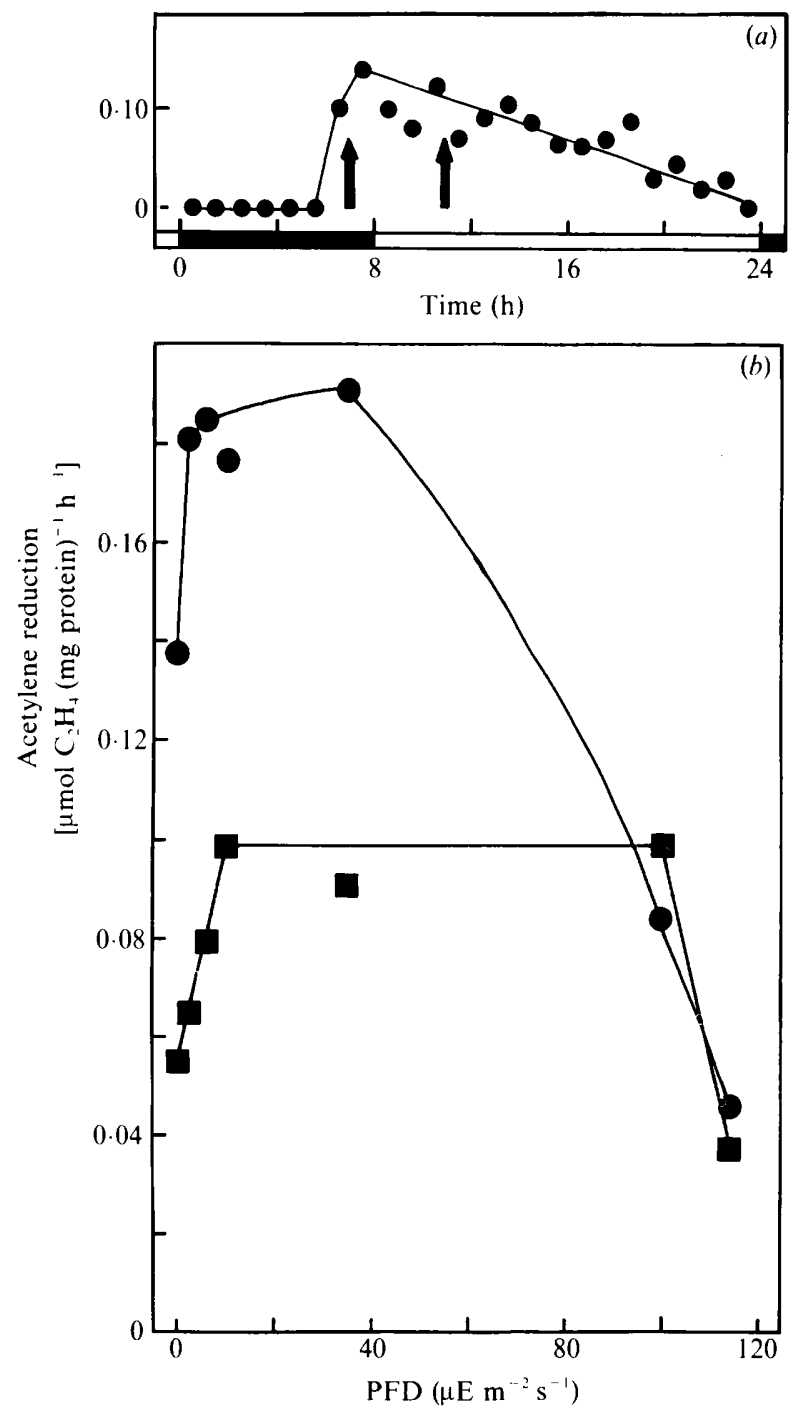

Fig. 2. Light response of acetylene reduction in Gloeothece sp. PCC 6909 grown in continuous culture at $D=0.005 \mathrm{~h}^{-1}$ under a $16-8 \mathrm{~h}$ light-dark cycle and a mean PFD of $25 \cdot 5 \mu \mathrm{E} \mathrm{m}^{-2} \mathrm{~s}^{-1}$. (a) Pattern of acetylene reduction during one light-dark cycle. Arrows indicate the times when samples were withdrawn for the light-response experiment shown in $(b)$. (b) Light response of acetylene reduction in samples withdrawn at the end of the dark phase (๑) and from a few hours after the light was switched on ( $\boldsymbol{\square})$

oxygen evolution was more or less constant at $1.25 \mu \mathrm{mol}$ $\mathrm{O}_{2} \mathrm{~h}^{-1}$ (mg protein $)^{-1}$. The glycogen content was determined and varied from $0.75-0.84 \mathrm{mg}(\mathrm{mg} \text { protein })^{-1}$ (Table 1). There was little change in glycogen content during the $24 \mathrm{~h}$ cycle.

The 12-12 h light-dark culture grew at $D=0.007 \mathrm{~h}^{-1}$. Virtually no nitrogenase activity was detected during the dark period (Fig. 1b). Nitrogenase activity was induced to a maximum immediately after the light was switched on and then decreased slowly to zero at the end of the
Table 4. Light dependence of acetylene reduction in Gloeothece sp. PCC 6909

Samples were taken during the light phase and incubated in the light or in the dark as indicated. Values are the average of triplicate samples \pm SE.

\begin{tabular}{crr}
\hline \hline & \multicolumn{2}{c}{$\begin{array}{c}\text { Acetylene reduction } \\
{\left[\mathrm{nmol}(\mathrm{mg} \text { protein })^{-1} \mathrm{~h}^{-1}\right]}\end{array}$} \\
\cline { 2 - 3 } $\begin{array}{c}\text { Culture dilution } \\
\text { rate }\left(\mathrm{h}^{-1}\right)\end{array}$ & \multicolumn{1}{c}{ Light } & Dark \\
\hline 0.005 & $91.0 \pm 15.4$ & $55.2 \pm 5.0$ \\
0.015 & $519.0 \pm 99.8$ & $112.2 \pm 0.2$ \\
\hline \hline
\end{tabular}

light period. Respiration was virtually constant at $1.25 \mu \mathrm{mol} \mathrm{O}_{2} \mathrm{~h}^{-1}$ (mg protein $)^{-1}$. Net photosynthetic oxygen evolution increased during the light period. The peak in nitrogenase activity coincided with a relatively low net photosynthetic activity $\left[1.56 \mu \mathrm{mol} \mathrm{O}_{2} \mathrm{~h}^{-1}(\mathrm{mg}\right.$ protein $)^{-1}$ ] which then approximately doubled after $8 \mathrm{~h}$ in the light. This culture accumulated and mobilized glycogen which decreased from $1.25 \mu \mathrm{g}$ (mg protein) ${ }^{-1}$ at the end of the light period to $0.58 \mu \mathrm{g}$ (mg protein $)^{-1}$ after a $12 \mathrm{~h}$ dark period (Table 1 ).

The cultures at $D=0.005$ and $0.015 \mathrm{~h}^{-1}$ were switched to continuous light in order to investigate the possibility of an endogenous rhythm. The switch to continuous light was followed during a $24 \mathrm{~h}$ period, starting with a $12 \mathrm{~h}$ dark period. The results of these experiments showed that there was no endogenous rhythm in Gloeothece sp. In both cultures, nitrogenase activity ceased and became virtually zero at the end of the $24 \mathrm{~h}$ period (data not shown).

The pattern of acetylene reduction in the culture grown at $D=0.005 \mathrm{~h}^{-1}$ and an incident irradiance of $79.8 \mu \mathrm{E} \mathrm{m}^{-2} \mathrm{~s}^{-1}$ is shown in Fig. 2(a). There was no nitrogenase activity during most of the dark period. Induction was observed at the end of the dark period, reached its maximum at the transition from dark to light and then slowly decreased until no activity was detected at the end of the light period. The effect of light intensity on acetylene reduction was determined in samples withdrawn at the end of the dark period when nitrogenase was induced and a few hours after the light was switched on. Both of these samples exhibited light stimulation although the maximum activity was obtained at very low incident irradiance $\left[5-10 \mu \mathrm{E} \mathrm{m}^{-2} \mathrm{~s}^{-1}\right.$, Fig. 2(b)]. The stimulation was greater in the sample withdrawn during the light period than the dark period, although the latter exhibited higher nitrogenase activity at all but the highest levels of light irradiance (Fig. $2 b$ ). At very high light intensities, a considerable decrease in acetylene reduction was observed. The sample from the light phase was clearly less sensitive to high light 
Table 5. Oxygen production and consumption by Gloeothece PCC 6909

\begin{tabular}{lcccc}
\hline \hline \multicolumn{2}{c}{ Culture conditions } & & \multicolumn{2}{c}{$\begin{array}{c}\text { Oxygen exchange rate } \\
{\left[\mu \mathrm{mol} \mathrm{O}_{2}(\mathrm{mg} \text { protein })^{-1} \mathrm{~h}^{-1}\right]}\end{array}$} \\
\cline { 5 - 6 }$D\left(\mathrm{~h}^{-1}\right)$ & $\begin{array}{c}\text { Light-dark } \\
\text { cycle }(\mathrm{h})\end{array}$ & & Light & Dark \\
\hline 0.005 & $16-8$ & & $1.40 \pm 0.13$ & $-0.51 \pm 0.13$ \\
0.015 & $16-8$ & & $1.22 \pm 0.05$ & $-0.92 \pm 0.09$ \\
0.020 & $16-8$ & & $1.48 \pm 0 \cdot 10$ & $-0.80 \pm 0.16$ \\
0.007 & $12-12$ & & $2.67 \pm 0.24$ & $-1.05 \pm 0.05$ \\
\hline \hline
\end{tabular}

intensity. At $100 \mu \mathrm{E} \mathrm{m}^{-2} \mathrm{~s}^{-1}$, the activity from the dark phase was reduced but the sample from the light phase was unaffected. At $114 \mu \mathrm{E} \mathrm{m}^{-2} \mathrm{~s}^{-1}$, the light-phase sample was also inhibited. The light dependence was even more pronounced in the culture grown at $D=0.015 \mathrm{~h}^{-1}$ (Table 4). A sample from the light phase incubated in the dark showed a 5 -fold decrease in the rate of acetylene reduction.

The oxygen-production and -consumption rates in the different cultures are compared in Table 5. Net oxygen production in the cultures grown under a $16-8 \mathrm{~h}$ lightdark cycle did not differ greatly. On the other hand, the 12-12 h light-dark culture showed rates of oxygen production that were twice as high as the $16-8 \mathrm{~h}$ lightdark cultures and the rate of respiration was also higher.

\section{Discussion}

The mechanism by which non-heterocystous cyanobacteria are able to fix nitrogen during photo-autotrophic growth is poorly understood. Although immunological studies to localize nitrogenase in Gloeothece have not been done, it seems very unlikely that in PCC 6909 there is a spatial separation of nitrogenase and photosynthesis in different cells. Such a cell differentiation could conceivably occur within the mucilagenous sheath of Gloeothece, but Kallas et al. (1983) showed that sheathless mutants were not altered in their capacity to fix nitrogen. In addition, the results presented here very clearly show that oxygenic photosynthesis and nitrogen fixation occur simultaneously. Hence, a temporal separation of oxygenic photosynthesis and nitrogen fixation cannot be the principal mechanism in Gloeothece for nitrogen fixation under photo-autotrophic conditions. Therefore, an alternative mechanism must be present.

By analogy with the heterocystous Anabaena variabilis (Ernst et al., 1990) we suggest that Gloeothece sp. PCC 6909 possesses a very effective oxygen scavenging mechanism to protect nitrogenase. In this model, photosynthetic electron transport covers the demand for reductant which is needed for the reduction of nitrogen and for oxygen scavenging. However, the model does not explain why nitrogenase is not inhibited by photosynthetically evolved oxygen. A spatial separation of both processes at the cellular level might also be feasible. The importance of respiration for nitrogen fixation in Gloeothece sp. PCC 6909 has been emphasized by Maryan et al. (1986). These authors proposed that respiration was important as a source of reductant and energy for nitrogenase. In an earlier paper, the same group implicated respiration in oxygen protection of nitrogenase (Gallon \& Hamadi, 1984). In contrast to what has been reported (Mullineaux et al., 1981; Stal \& Krumbein, 1985), we have shown that nitrogenase activity in Gloeothece sp. PCC 6909 is clearly confined to the light period of a light-dark cycle. In our hands, nitrogenase activity was also clearly light-stimulated (Fig. 2 and Table 4), regardless of the dilution rate of the culture or whether the samples were taken from the dark or the light phase. One could argue that respiration should result in a lowering of the oxygen in the cell during the dark period and thus allow nitrogenase to function. However, it seems likely that in the dark, when there is sufficient oxygen, there will be a strong competition for electrons between the respiratory electron transport chain and nitrogenase, with the consequence that the latter does not function.

In Anabaena variabilis, respiratory protection of nitrogenase is mediated through the mobilization of glycogen (Ernst et al., 1990). The glycogen content of Gloeothece sp. PCC 6909 cells (Table 1) reflected the different degrees of nitrogen limitation. Nitrogen-limited cyanobacteria contain high amounts of glycogen (Lehmann \& Wöber, 1976). In our experiments, a higher degree of nitrogen limitation is expected when higher dilution rates or short light-periods are applied. In such cultures the specific rate of photosynthetic oxygen production will be higher, resulting in less-efficient nitrogen fixation. In none of the $16-8 \mathrm{~h}$ light-dark cultures of Gloeothece sp. PCC 6909 was a substantial accumulation or mobilization of glycogen found. It made no difference whether the actual amount of glycogen in the cultures was low or high. This was remarkable because it is known that cyanobacteria grow during the dark at the expense of glycogen (Mur, 1983). On the other hand, in the 12-12 h light-dark culture we detected substantial mobilization of glycogen in the dark and accumulation in the light $\left.[0.67 \mathrm{mg} \text { glycogen (mg protein })^{-1}\right]$ (Table 1$)$. If we take into account the rate of respiration $(1.05 \mu \mathrm{mol}$ $\mathrm{O}_{2}$ (mg protein $)^{-1} \mathrm{~h}^{-1}$, Table 5) we can calculate that $0.38 \mathrm{mg}$ glycogen $(\mathrm{mg} \text { protein })^{-1}$ was respired. Presumably, the rest of the glycogen was used for the synthesis of structural cell material. Making the same calculation for the $16-8 \mathrm{~h}$ light-dark cultures, the rate of respiration was 
found to be much higher (Table 5) than was expected on the basis of the very small amount (if any) of glycogen that was used (Table 1). These observations make it unlikely that glycogen is involved in nitrogen fixation in Gloeothece in the way proposed for A. variabilis by Ernst et al. (1990). A second conclusion that can be made is that glycogen-independent oxygen uptake might be related to the relatively small but significant nitrogenase activity that was seen in the dark phase of the 16-8 h light-dark cultures. Maryan et al. (1986) noted the existence of an oxygen-uptake system in Gloeothece sp. PCC 6909 which was not coupled to ATP generation. An oxygen-uptake system of this kind might be involved in the protection of nitrogenase. This point deserves a more detailed investigation.

The shorter period during which photosynthesis can take place in the 12-12 h light-dark culture compared to the 16-8 h light-dark culture resulted in an increased net oxygen production in the former culture, as well as an increased rate of dark respiration. From this it may be expected that cultures with even shorter light periods, such as the 8-16 h light-dark culture, would show even higher rates of photosynthetic oxygen production. This would presumably exceed the capacity of the organism to efficiently protect nitrogenase against oxygen so that diazotrophic growth would not be possible. Similarly, oxygen production in the $12-12 \mathrm{~h}$ light-dark culture would allow only a limited nitrogenase activity so that the maximum growth rate that can be obtained under this condition will be relatively low. Fig. 1 gives clear evidence for an inverse relationship between net photosynthetic oxygen evolution and nitrogenase activity. In the 12-12 h light-dark culture, especially, net photosynthetic oxygen evolution is considerably reduced during the peak of nitrogenase activity. In the 16-8 h light-dark culture, the rate of respiration increased when nitrogenase was induced.

The question of why the experiments presented here revealed such a different pattern of nitrogenase activity in light-dark cycles than reported previously, is still not answered. One of the major differences between the continuous cultures used here and the batch-culture experiments used by others might be the aeration. The continuous cultures used by us were well-mixed and wellaerated to ensure that in the dark oxygen did not drop below air saturation, and that in the light supersaturation did not occur. This may easily be the case in batch cultures that are shaken, bubbled or just standing. If a culture is not aerated sufficiently well, supersaturation of oxygen may occur in the light. A high oxygen concentration is incompatible with the fixation of nitrogen since it may exceed the capacity of the oxygen-scavenging mechanism. In the dark, because of diffusion limitation, oxygen levels may be low. Low oxygen levels, of course, are beneficial for nitrogenase and the reduced respiration may result in an improved electron supply for nitrogenase (i.e. there will be less competition for electrons). Dark conditions, especially when little oxygen is available, are unfavourable for the high energy demand of nitrogenase. Indeed, literature data often report comparatively low nitrogenase activities in the dark (Mullineaux et al., 1981; Gallon et al., 1988). These facts explain why in such cultures nitrogenase is confined to the dark phase of a light-dark grown culture. In the well-aerated cultures used in the experiments described in this paper, the situation is reversed since the culture is always saturated with oxygen. In the dark, nitrogenase is unable to compete with oxygen for electrons. In the light, provided that net oxygen evolution is not exceedingly high, as for example when very short light-periods and long dark-periods are used, or at too high a level of incident irradiation, supersaturation of oxygen does not occur and an effective oxygen-scavenging mechanism becomes operative, allowing nitrogenase to function. Also, in the light, sufficient energy will be available. As shown in Table 2, acetylene reduced, integrated over a $24 \mathrm{~h}$ period, was converted into nitrogen fixed. The specific growth rate is defined as the increase of biomass in time as a function of the biomass $\left(\mathrm{h}^{-1}\right)$. During balanced growth the rate of increase in cell nitrogen will be the same as the increase in biomass. Therefore, the specific rate of increase of cell nitrogen equals the specific growth rate. The specific rate of nitrogen fixation (as a function of the cellular nitrogen content) must have the same value as the specific growth rate. We obtained values that were 2- and 2.5-fold too low for the cultures grown at $D=0.015$ and $0.005 \mathrm{~h}^{-1}$, respectively (Table 2). However, considering the uncertainties that are associated with such calculations (Stal, 1988) these values match reasonably well with the growth rate of the organism. The air that was used for aeration might also have contained a little ammonia which would explain the somewhat low specific rate of nitrogen fixation. Although care was taken to perform the acetylene reduction assays under conditions that reproduced the culture conditions as closely as possible, small differences may have influenced the measured activities. At $D=0.020 \mathrm{~h}^{-1}$ the culture was washed out slowly, probably because the specific rate of nitrogen fixation $\left(0.003 \mathrm{~h}^{-1}\right)$ was approximately 7 -fold lower than required. However, efficient nitrogen fixation by Gloeothece sp. PCC 6909 allowed a relatively high specific maximum growth rate, which would be close to $0.020 \mathrm{~h}^{-1}$ (doubling time $35 \mathrm{~h}$ ).

The pattern of nitrogenase presented here is of limited relevance for the natural function of nitrogenase in nonheterocystous cyanobacteria. Well-aerated cultures do not always mimic the natural system. Benthic communi- 
ties of cyanobacteria (e.g. cyanobacterial mats) or cyanobacteria in stagnant water bodies (e.g. paddy fields) are usually characterized by supersaturation with oxygen during the day, whereas low oxygen or even anoxic conditions prevail during the night. This might apply to Gloeothece populations which are often found on limestone (Whitton \& Sinclair, 1975) or in paddy fields (Huang \& Chow, 1988). Natural rhythms of nitrogenase very often show the typical diurnal pattern in which nitrogenase activity is confined to the dark (Griffiths et al., 1987; Villbrandt et al., 1990). With this in mind it is especially interesting to look at the diurnal pattern of nitrogen fixation of the marine planktonic Trichodesmium. This non-heterocystous cyanobacterium occurs in well aerated sea water and natural populations of this organism also show the strictly light-dependent nitrogenase activity (Saino \& Hattori, 1978) as shown for Gloeothece sp. PCC 6909 in this paper.

The results discussed here indicate that the mechanism of nitrogenase protection in the non-heterocystous cyanobacterium Gloeothece sp. PCC 6909 may not involve a temporal separation of photosynthesis and nitrogen fixation, but most probably employs a similar but conceivably more powerful oxygen uptake mechanism to that demonstrated for the heterocystous Anabaena variabilis.

This research was partially supported by the CEC through contract EV4V 0061 E and CICYT (PAT89-0767-CO4), Spain. We thank Drs L. R. Mur and H. R. Moezelaar for valuable discussions.

\section{References}

De Wit, R. \& Van Gemerden, H. (1990). Growth of the phototrophic purple sulfur bacterium Thiocapsa roseopersicina under oxic/anoxic regimens in the light. FEMS Microbiology Ecology 73, 69-76.

ERNST, A., REICH, S. \& Böger, P. (1990). Modification of dinitrogenase reductase in the cyanobacterium Anabaena variabilis due to C starvation and ammonia. Journal of Bacteriology 172, 748-755.

Gallon, J. R. \& Chaplin, A. E. (1988). Recent studies on $\mathrm{N}_{2}$ fixation by non-heterocystous cyanobacteria. In Nitrogen Fixation: Hundred Years After, pp. 183-188. Edited by H. Bothe, F. J. de Bruijn \& W. E. Newton. Stuttgart: Gustav Fischer.

Gallon, J. R. \& Hamadi, A. F. (1984). Studies on the effects of oxygen on acetylene reduction (nitrogen fixation) in Gloeothece sp. ATCC 27152. Journal of General Microbiology 130, 495-503.

Gallon, J. R., Perry, S. M., Rajab, T. M. A., Flayeh, K. A. M., YUNES, J. S. \& ChAPLIN, A. E. (1988). Metabolic changes associated with the diurnal pattern of $\mathrm{N}_{2}$ fixation in Gloeothece. Journal of General Microbiology 134, 3079-3087.

Griffiths, M. S. H., Gallon, J. R. \& Chaplin, A. E. (1987). The diurnal pattern of dinitrogen fixation by cyanobacteria in situ. New Phytology 107, 649-657.

GrobbelaAr, N., Huang, T. C., Lin, H. Y. \& Chow, T. J. (1986). Dinitrogen-fixing endogenous rhythm in Synechococcus RF-1. FEMS Microbiology Letters 37, 173-177.
GrobbelaAr, N., Lin, H.-Y. \& HUang, T.-C. (1987). Induction of a nitrogenase activity rhythm in Synechococcus and the protection of its nitrogenase against photosynthetic oxygen. Current Microbiology 15, 29-33.

Herbert, D., Phipps, P. J. \& Strange, R. E. (1971). Chemical analysis of microbial cells. Methods in Microbiology 5B, 209-344.

HuANG, T.-C. \& ChOw, T.-J. (1988). Comparative studies of some nitrogen-fixing unicellular cyanobacteria isolated from rice fields. Journal of General Microbiology 134, 3089-3097.

Huang, T.-C., Tu, J., Chow, T.-J. \& Chen, T.-H. (1990). Circadian rhythm of the prokaryote Synechococcus sp. RF-1. Plant Physiology 92, 531-533.

JENSEN, B. B. \& Cox, R. P. (1983). Direct measurements of steady-state kinetics of cyanobacterial $\mathrm{N}_{2}$ uptake by membrane-leak mass spectrometry and comparisons between nitrogen fixation and acetylene reduction. Applied and Environmental Microbiology 45, $1331-1337$.

Kallas, T., Rippka, R., Cousin, T., Rebiere, M. C., Tandeau de MARSAC, N. \& CoHEN-BAzIRE, G. (1983). Aerobic nitrogen fixation by non-heterocystous cyanobacteria. In Photosynthetic Prokaryotes, Cell Differentiation and Function, pp. 281-302. Edited by G. C. Papageorgiou \& L. Packer. Amsterdam: Elsevier Biomedical.

LeHMANN, M. \& WöBER, G. (1976). Accumulation and turn-over of glycogen in the blue-green bacterium Anacystis nidulans. Archives of Microbiology 111, 93-97.

Leon, C., Kumazawa, S. \& Mitsui, A. (1986). Cyclic appearance of aerobic nitrogenase activity during synchronous growth of unicellular cyanobacteria. Current Microbiology 13, 149-153.

MACKINNEY, G. (1941). Absorption of light by chlorophyll solutions. Journal of Biological Chemistry 140, 315-322.

Maryan, P. S., Eady, R. R., Chaplin, A. E. \& Gallon, J. R. (1986). Nitrogen fixation by Gloeothece sp. PCC 6909: respiration and not photosynthesis supports nitrogenase activity in the light. Journal of General Microbiology 132, 789-796.

Mrtsui, A., Kumazawa, S., Takahashi, A., IKemoto, H., Cao, S. \& ARAI, T. (1986). Strategy by which nitrogen-fixing unicellular cyanobacteria grow photo-autotrophically. Nature, London 323, 720-722.

Mitsui, A., Cao, S., Takahashi, A. \& Arai, T. (1987). Growth synchrony and cellular parameters of the unicellular nitrogen-fixing marine cyanobacterium, Synechococcus sp. strain Miami B6 043511 under continuous illumination. Physiologia Plantarum 69, 1-8.

Mullineaux, P. M., Gallon, J. R. \& Chaplin, A. E. (1981). Acetylene reduction (nitrogen fixation) by cyanobacteria grown under alternating light-dark cycles. FEMS Microbiology Letters 10, 245-247.

MUR, L. R. (1983). Some aspects of the ecophysiology of cyanobacteria. Annales de Microbiologie de l'Institut Pasteur 134B, 61-72.

Rippka, R., Deruelles, J., Waterbury, J. B., Herdman, M. \& StANIER, R. Y. (1979). Generic assignments, strain histories and properties of pure cultures of cyanobacteria. Journal of General Microbiology 111, 1-61.

Robson, R. L. \& Postgate, J. R. (1980). Oxygen and hydrogen in biological nitrogen fixation. Annual Review of Microbiology 34, 183-207.

SAINO, T. \& HATTORI, A. (1978). Diel variation in nitrogen fixation by a marine blue-green alga, Trichodesmium thiebautii. Deep-Sea Research 25, 1259-1263.

STAL, L. J. (1988). Nitrogen fixation in cyanobacterial mats. Methods in Enzymology 167, 474-484.

Stal, L. J. \& Krumbein, W. E. (1987). Temporal separation of nitrogen fixation and photosynthesis in the filamentous, nonheterocystous cyanobacterium Oscillatoria sp. Archives of Microbiology 149, 76-80.

STAL, L. J. \& KrUMbein, W. E. (1985). Nitrogenase activity in the nonheterocystous cyanobacterium Oscillatoria sp. grown under alternating light-dark cycles. Archives of Microbiology 143, 67-71.

VAN LIERE, L. \& MUR, L. R. (1978). Light limited cultures of the bluegreen alga Oscillatoria agardhii. Mitteilungen der Internationalen Vereinigung für Theoretische und Angewandte Limnologie 21, 158-167. 
VAN LIERE, L., LOOGMAN, J. G. \& MUR, L. R. (1978). Measuring lightirradiance in cultures of phototrophic micro-organisms. FEMS Microbiology Letters 3, 161-164.

Villbrandt, M., Stal, L. J. \& Krumbein, W. E. (1990). Interactions between nitrogen fixation and oxygenic photosynthesis in a marine cyanobacterial mat. FEMS Microbiology Ecology 74, 59-72.
Whitton, B. A. \& Sinclair, C. (1975). Ecology of blue-green algae. Science Progress 62, 429-446.

WoLK, C. P. (1982). Heterocysts. In The Biology of Cyanobacteria, pp. 359-386. Edited by N. G. Carr \& B. A. Whitton. Oxford: Blackwell. WyatT, J. T. \& SilveY, J. K. G. (1969). Nitrogen fixation by Gloeocapsa. Science 165, 908-909. 